УДК 33 (091)

\title{
ЕКОНОМІКА НАДДНІПРЯНСЬКОЇ УКРАЇНИ У ПЕРШІЙ ПОЛОВИНІ ХІХ СТ.: СОЦІАЛЬНО-ЕКОНОМІЧНІ ЗМІНИ
}

\section{Довжук Ігор}

Розглядається економічний розвиток українських губерній $у$ передреформений період. Акиентовано увагу на таких галузях промисловості як мануфактурна, машинобудівна, металообробна. Утвердження товарногромових відносин впливало на національну самосвідомість значної частини украӥнського етносу.

Зазначено, що ияарський режим насамперед відстоював імперські інтереси, проте не міг не враховувати потребу промислового розвитку окраїн, їхніх природних багатств. Політика протекціонізму сприяла розвитку металургійної та машинобудівної галузей Украйни, зокрема, південних регіонів. Ця політика посилилась після Кримської війни. Держава надавала підприємиям допомогу шияхом державних замовлень, субсидій, премій, пільгових тарифів тощо. Однак у иих умовах розвиток приватної ініиіативи нижчих станів був обмежений. Царський уряд доклав усі зусилля для створення ідеальних умов для підприємницької діяльності дворянства та купиів.

Особливістю українського робітничого класу передреформеної доби був його тривалий зв'язок із сільським господарством. $У$ передреформені десятиріччя головним джерелом формування робітничого класу в Украӥні було селянство. Лише пізніше машинна індустрія цілком відривала робітників від землі.

У процесі капіталістичного розвитку Україна все глибще втягувалась у Російську імперську систему. Проте утвердження товарно-грошових відносин впливало на національну самосвідомість значної частини украйнського етносу. Долався середньовічний ізолящіонізм, відбувалися структурні зміни у складі населення. Нова різночинна інтелігенція та кращі представники національної буржуазії стали носіями украӥнського наиіонального відродження.

Ключові слова: Украӥна, українські губернії, промисловість, мануфактура, селянин, кріпосництво, гужовий транспорт, залізниці.

У Наддніпрянській Україні у другій чверті XIX ст. розпочався промисловий переворот. Поступово долався економічний ізоляціонізм середньовічного натурального господарства, складались економічні умови формування української модерної нації. Товарно-грошове господарство, що приходило на зміну натуральному, сприяло розширенню економічних зв'язків між окремими регіонами українських земель, вносило зміни в 
соціальну структуру суспільства, сприяло формуванню інтелігенції, національної буржуазії, здатних генерувати ідеї національного відродження.

Мета цієї розвідки - показати економічні зміни в українських землях, що перебували під владою Російської імперії у передреформений період та їхній вплив на формування модерної української нації. Цю проблему так чи інакше розглядали у свої працях Т. Г. Гончарук, Г. І. Марахов, Б. Д. Лановик, T. І. Лазанська та інші науковці.

У першій третині ХІХ ст. більшість підприємств України становили міські та сільські кустарні промисли (ремісничі майстерні), мануфактури, засновані на ручній техніці та примусовій праці кріпаків. Кустарне виробництво орієнтувалось на невизначений ринок, а кустар був водночас підприємцем i виробником. Ремісниче виробництво існувало завдяки замовленням і за рахунок замовника. Ремісник докладав лише свою працю та власний інструмент. Кустарна промисловість була пов'язана 3 наявністю сировини та безпосереднім впливом довкілля. Важливим спонукальним чинником до занять кустарництвом ставала втрата зв'язку із землеробством у процесі поглиблення майнового розшарування селянства.

Існувало два види мануфактур - кріпосницька та капіталістична. У свою чергу кріпосницька мануфактура підрозділялася на вотчинну та посесійну. Вотчинна мануфактура грунтувалася на примусовій праці кріпосних селян і в здебільшого мала натуральний характер. Посесійна мануфактура спиралася на працю селян, які були приписані для роботи на промислових підприємствах. На відміну від вотчинних, ці мануфактури створювалися в здебільшого особами недворянського походження [10, 25]. Капіталістичні мануфактури належали переважно купцям, міщанам, та селянам, які звільнилися від кріпосної залежності. Засновані на вільнонайманій праці, ці мануфактури швидко зростали i працювали на ринок [14, 25]. Для забезпечення мануфактури робочими руками підприємці здійснювали різноманітні заходи: оголошували про прийом на роботу, завчасно укладали трудові угоди, прикріпляли робітників до підприємства.

Чисельність промислових підприємств в Україні з 1832 до 1861 рр. зросла майже у 4 рази (з 752 до 2873), 72 \% з них знаходилося в селах, 10 \% у губернських і $18 \%$ - у повітових містах [4, 16]. Феодальна вотчина втрачала натуральний характер і поступово перетворювалася на товарне господарство. Зростали обсяги товарної продукції та зв'язки з ринком [5, 227, 232].

Зрозуміло, що значна частина підприємств спиралися на кріпосну працю низької продуктивності, що послаблювало їхню конкурентоспроможність. Кріпосницькі промислові підприємства, засновані на примусовій праці, не витримували конкуренції з капіталістичним виробництвом і в 60-х роках перестали існувати [14, 28].

Збільшення кількості мануфактур, фабрик i заводів, що діяли на найманій праці, поява нових галузей промислового виробництва - усе це 
свідчило про розвиток товарного виробництва. Товарно-грошове господарство руйнувало підвалини феодально-кріпосницької системи, сприяло економічному згуртуванню українського населення. У середині XIX ст. розвивалися такі галузі виробництва, як машинобудування, металообробка. Наприкінці 50-х років в Україні діяло 11 чавуноливарних і 32 залізоробних заводів. За кількістю видобутого вугілля Донбас вийшов в середині століття на друге місце в Російській імперії, поступаючись тільки польській Сілезії [12, 240-242].

Розвивалися суконна, тютюнова, склодувна, паперова, харчова промисловості. Особливо слід виділити цукрову промисловість, яка забезпечувала 80 \% виробництва цукру в Російській імперії. У 40-і pp. ХІХ ст. темпи розвитку цукрової промисловості дещо знизилися, але залишалися досить високими. Лише в 50-х роках розвиток цукрової промисловості значно збільшується. У 1857 р. в Україні вже діяло 218 цукрових заводів, що становило 70 \% від їхньої кількості в Російській імперії.

31844 р. політика імперського уряду в цукровій галузі характеризувалася коливанням від помірно-протекціоністської до ліберальної, коли, незважаючи на зменшення мита на іноземний цукор та введення акцизу, уряд усіляко підтримував вітчизняного виробника, хоча безпосередньо не втручався у розвиток галузі [1, 12, 14-15].

Розвивалася військова промисловість. В Україні діяли такі військові підприємства, як завод «Арсенал» у Києві, що випускав зброю, Шосткінський пороховий завод, Луганський чавуноливарний завод, канатний i суднобудівний заводи в Миколаєві.

У середині століття посилюється процес формування всеукраїнського (у межах всеросійського) внутрішнього ринку. У його орбіту включаються нові території, зростають економічні зв'язки з віддаленими районами України [5, 264]. Прикладом цьому може бути інтенсивна інтеграція Бессарабіі, включеної до складу Росії у 1812 р. і господарство Півдня України.

Формування всеросійського ринку об'єктивно сприяло подоланню тих соціально-економічних відмінностей, які реально існували між окремими регіонами українських земель. Велику роль у процесі інтеграції українських земель відігравали ярмарки. У 40-х роках в Україні їх діяло 12 тис., у тому числі 178 великих і середніх. Найважливішими з них були Контрактовий у Києві, Введенський у Сумах, Хрещенський, Успенський, Покровський у Харкові, Петропавлівський у Катеринославі [2, 21].

У посиленні формування єдиного ринку, економічних зв'язків між окремими регіонами, важливу роль відіграє розвиток транспорту. Від його стану залежало подальше зростання продуктивних сил. Для України, де річкове судноплавство було розвинене в середині ХІХ ст. слабо, а залізниць ще не було, проблема транспорту мала важливе значення. Основну роль відігравали перевезення суходолом. У 40-50-х роках у Степовій Україні перевезення волами були у 2-3 рази дешевше, ніж кіньми. Важливим 
напрямком перевезень у середині століття став Новоросійський край, який швидко опановувався [18, 8].

У середині ХІХ ст. в Україні переважав гужовий транспорт. 3 українських губерній за кордон через азовські та чорноморські порти чумаки перевозили 75 \% хліба (до 640 тис. т щорічно) [12, 309].

У дореформене десятиріччя було складено ряд проектів будівництва залізниць в Україні. Проте Кримська війна не дозволила їх реалізувати. Провідна роль належала стратегічним шляхам - від Києва та від Харкова до Петербурга. Повільно розвивався річковий транспорт. У 1823 р. на Дніпрі 3'явився перший пароплав. У 1838 р. створено Дніпровську судноплавну компанію. У Дніпровському басейні в 1852 р. налічувалося лише 7 пароплавів загальною потужністю 360 к. с. Після Кримської війни з'являються пароплавні товариства й компанії. У 1859 р. Дніпром і його притоками курсувало 17 пароплавів, серед них 3 пасажирських, решта - буксири. Зростав вантажообіг чорноморсько-азовських портів. Основна частина вантажообігу здійснювалася парусними суднами [12, 309]. Найбільшими портами в Україні були Херсон, Одеса, Миколаїв.

Розбудові парового суднобудування в Україні сприяло вигідне географічне розташування регіону: наявність портів Чорного та Азовського морів, багатих родовищ кам'яного вугілля, залізної руди, зростання ваги України у зовнішній торгівлі Російської імперії [16, 29].

Царський уряд сприяв суднобудівництву. У 1830 р. «для підтримки каботажного флоту на Чорному та Азовському морях було віддано купцям Херсонську верф» $[17,122]$. У цьому ж році Микола I підписав указ про привілеї вітчизняних суден у каботажному плаванні.

У 20-50-х роках цивільне суднобудування перебувало переважно у приватних руках. Для пасажирських і вантажних перевезень на Чорному та Азовському морях у 1827-1855 рр. суднобудівні верфі України будували: у Миколаєві - 16 пароплавів, Одесі - 1, у Київській губернії (м. Мошни) - 1, на Луганському ливарному заводі - 1. Крім того, у ці роки в Англії було придбано 28 суден [7, 108-115].

Після Кримської війни державні заводи Російської імперії будували переважно військові кораблі, бо цивільне суднобудування вважалося малоперспективним. Розвиток торговельного флоту йшов за рахунок придбання суден за кордоном. Приватне суднобудування в країні орієнтувалося на спорудження суден малого каботажу. Недооцінка великого каботажу, обмеженість коштів, будівництво таких суден у зарубіжних країнах гальмували розвиток вітчизняного суднобудування. Росія була чи не єдиною країною Європи, де морському комерційному суднобудівництву не приділялося належної уваги [6, 788].

17 травня 1856 р. флігель-ад’ютант, капітан першого рангу М. Аркас та статський радник М. Новосельський надіслали міністру фінансів прохання про заснування на Чорному морі Російського акціонерного товариства 
пароплавства і торгівлі (далі - РТПіТ), основною метою якого мало бути прискорене формування на Півдні України парового торгового флоту. Уряд підтримав цю ініціативу. РТПіТ створив власну судноремонтну i суднобудівну бази. Йому передали за умовами безоплатної аренди Лазаревське Адміралтейство у Севастополі, де розпочалося будівництво суднопідйомного елінгу вантажопідйомністю 3 тис. т. В Англії, у фірми Мортона, засновники РТПіТ закупили необхідні механізми і конструкції. Будівництво елінгу тривало з 1856 по 1861 pp. [16, 30].

У середині ХІХ ст. починається будівництво шляхів сполучення: 3'являється перша залізниця, будуються шосейні дороги, споруджуються нові канали, розширюється пароплавне сполучення на Чорному та Азовському морях $[5,244,264]$. У результаті мережа транспортних сполучень об'єднала економічно розрізнені райони України в єдиний економічний простір. На околицях імперії з'явилося більше можливостей для розгортання підприємницької діяльності $[11,7,173]$.

Утвердження капіталістичних відносин у промисловості й сільському господарстві, господарська спеціалізація районів, розширення внутрішнього ринку, розвиток внутрішньої і зовнішньої торгівлі, будівництво шляхів сполучення - усе це розхитувало господарську замкнутість окремих районів України, сприяло єдності економічного життя українського народу, етнічній консолідації, створювало підстави для націотворення.

Одночасно відбуваються структурні зміни у складі населення України. Так, утвердження ринкових відносин в 40-50-х роках сприяло зростанню чисельності підприємців, найманих робітників, технічної та гуманітарної інтелігенції (лікарі, адвокати, вчителі). Крім селян, які традиційно були носіями національних традицій, формувалися соціальні сили (підприємці, робітники, нова інтелігенція), які здатні творити модерну націю. За соціальним складом в середині XIX ст. серед промисловців переважали поміщики, які складали 40,5 \%, купці становили - 27,8 \%, міщани - 23,3\%, селяни $-2,3 \%[11,74]$.

Зазначимо, що головним гальмом на шляху зростання національної свідомості було кріпацтво та самодержавство, що відстоювало інтереси дворян, тримало національну людність у лещатах імперського режиму. У цей час лише поодиноким представникам із низів вдавалося, розірвавши пута кріпосної неволі, пробитися до лав вільних підприємців. Це були козаки, державні селяни, колоністи. Вони ставали власниками переважно дрібних та середніх підприємств.

Про діяльність купецтва говорять посвідчення на підприємницьку діяльність. Посвідчень першої гільдії та першого і другого класу другої гільдії, що стосувалися великих торгових і промислових закладів, в Україні нараховувалося 4222, або 17,8 \% від їхнього загального числа в Європейській Росії. Посвідчень третього-п'ятого класів власникам середніх і дрібних підприємств було видано 13812, або 22,8 \%. Найбільш активним у 
підприємницькій діяльності ставало купецтво південних губерній України (видано 5249 посвідчень) та Правобережжя (видано 4761 посвідчення) $[11,75,80]$.

Початком помітного зростання кількості репрезентантів української національної буржуазії слід вважати середину XIX ст., що пов'язане 3 процесом становлення капіталістичних відносин. Царська влада повільно змінювала свою політику щодо підприємців, прагнучи залучити до інвестування більшість буржуазії.

Представниками нової української буржуазії були такі славетні родини, як Тарновські, Терещенки, Яхненки, Симиренки. Їхня приватна ініціатива спрямовувалася в певні сфери суспільного життя. Освічені люди отримували можливість займатися наповненою змістом суспільною діяльністю. А якщо ця діяльність наповнювалася конкретним національним змістом, то на порядок денний поставала проблема фінансової підтримки українського національного руху. Фінансова база українського відродження передбачала не лише наявність у певних членів українського суспільства вільних коштів, а насамперед українофільські погляди, моральну свідомість, національну самоповагу. Вихід на історичну арену різних типів меценатів можна вважати частиною українського національного відродження як націотворчого процесу, перетворення етнічно-мовної спільноти на самосвідому політичну й культурну еліту $[19,13,15]$.

Зазначимо, що на післяреформений період припадає підприємницька діяльність родини Терещенків. Засновником імперії Терещенків був Артем Якович (?-1873), який, скориставшись указом 1803 р. «Про вільних хліборобів», викупився 3 кріпацтва і став займатися дрібною торгівлею. Пізніше до справи приєдналися його сини Микола (Нікола), Федір та Семен. Справжній підприємницький успіх до них прийшов під час Кримської війни, коли Терещенки постачали для армії ліс, провіант тощо. Нові можливості для збагачення відкрилися перед підприємцеми і під час реформи 1861 р. Ними сповна скористалися Терещенки. Вони заходилися активно скуповувати маєтки, будувати цукроварні та інші промислові заклади.

Посівши найвищі сходинки в ієрархічній структурі суспільства та досягнувши вершин фінансового процвітання, Терещенки долучилися до традиційних занять представників аристократичного світу: меценатства та колекціонування творів мистецтва і старожитностей. За розмахом своєї меценатської діяльності Терещенки не поступалися московським купцям Третьяковим. До того ж їхнє художнє зібрання було безцінним [11, 133, 209].

Унаслідок промислового розвитку з'являється нова українська буржуазія, яка значною мірою сприяла національному розвитку українського народу. Головним представником фірми братів Яхненків і Симиренка був Кіндрат Михайлович Яхненко. Він успадкував iї у 1843 р. після смерті батьків. Уже у 20-ті роки Яхненки і Симиренко володіли капіталом у 6-7 тис. руб. Але справжній розквіт і славу фірма здобула в 40-х роках, коли 
почала вкладати свої капітали у цукрову промисловість $[11,187-188,190]$. Їхні підприємства, зосередившись на якісному покращенні виробництва i використовуючи передову техніку та більш продуктивну найману працю, успішно конкурували 3 поміщицькими.

Родина Яхненків-Симиренків зробила величезний внесок в економічне процвітання краю. Їх представники були видатними меценатами національної культури. На суспільні погляди та свідомість Василя Федоровича Симиренка вплинула зустріч 3 українськими вченими, громадівцями Ф. Кістяківським та П. Чубинським, особливо близькі стосунки склались у нього $з$ В. Антоновичем, який став головним посередником у його громадській праці, спрямованій на розвиток освіти, науки і культури $[9,13]$.

Дворяни нерідко віддавали в оренду свої підприємства більш енергійним представникам інших станів. Так Ізраїль Бродський узяв в оренду у поміщика Роговського Лебединський цукровий завод на Черкащині та модернізував його (після дворічної оренди Роговський продав завод Бродському). Одночасно Бродський орендував Матусівський цукровий завод генерала Орлова у Чигиринському повіті. Купці другої гільдії П. Лепп і А. Вальман заснували у Катеринославському повіті ливарний і машинобудівний заводи $[11,120,126]$.

Зазначимо, що в середині століття більш інтенсивно формується українська національна буржуазія недворянського походження. Вона була зацікавлена передусім у власному збагаченні. У цілому іiі інтереси не відрізнялися від інтересів буржуазії інших націй. Проте в процесі капіталістичного розвитку української буржуазії доводилося дедалі частіше конкурувати в підприємницькій діяльності 3 капіталістами Росії, які мали більші капітали й значний практичний досвід. У цій боротьбі українська буржуазія поступово починала усвідомлювати свої національні інтереси спочатку в особі окремих іiї представників, а згодом і більш широкого загалу.

Підкреслимо, що царський режим насамперед відстоював імперські інтереси, проте не міг не враховувати потребу промислового розвитку окраїн, їхніх природних багатств. Політика протекціонізму (охоронні тарифи, державні замовлення, кредитування) сприяла розвитку металургійної та машинобудівної галузей України, зокрема, південних регіонів. Ця політика посилилась після Кримської війни. Держава надавала підприємцям допомогу шляхом держзамовлень, субсидій, премій, пільгових тарифів тощо. Однак у цих умовах розвиток приватної ініціативи нижчих станів був обмежений. Царський уряд доклав усі зусилля для створення ідеальних умов для підприємницької діяльності дворянства та іменитих купців $[11,8,147,220]$.

Російський уряд усіляко підтримував підприємців російського походження. Російські підприємці серед населення України, що жило 3 прибутків від капіталів, на середину століття становили $38,6 \%$, українські 29,1 , польські - 9, єврейські - 15,7\%. Торгівлею та торгово-кредитними операціями займалося $16,2 \%$ росіян, $13,4 \%$ українців, $1 \%$ поляків і 
$63,7 \%$ євреїв. У цей час у промисловому виробництві Півдня і Правобережжя різко зростає чисельність росіян. На Правобережжі російським дворянам за низькими цінами було продано 500 тис. дес. землі відібраної у поляків $[11,169,175]$. Лише на Лівобережжі українці та представники інших національностей могли конкурувати в підприємництві з росіянами.

Промисловий переворот сприяв формуванню робітничого класу. Одним iз проявів цього процесу протягом першої половини XIX ст. було заробітчанство. Чисельність селян, які через розорення своїх господарств змушені були йти на заробітки, напередодні реформи 1861 р. становила сотні тисяч. В умовах кріпосництва розорення селянства мало риси первісного нагромадження, але специфічного, оскільки селянин звільнявся від засобів виробництва, але не ставав особисто вільним, залишаючись у залежності або від поміщика, або від імперської держави. Селяни-заробітчани поповнювали населення міст, особливо Південної України, наймаючись на купецькі та казенні промислові підприємства $[15,53]$.

Особливістю формування промислового пролетаріату України було те, що він поповнювався не лише за рахунок місцевого населення, але й у значній мірі за рахунок вихідців із російських губерній. Відбувалася своєрідна робітнича колонізація українських земель підприємцями російського походження $[15,54]$. Національна строкатість робітників України накладала відбиток на сприйняття нових модерних ідей, впливала не лише на характер згуртування робітників, а й гальмувала пробудження національної самосвідомості.

У середині ХІХ ст. робітники поділялися на дві основні групи: вільнонаймані й кріпосні. Переважна маса робітників-кріпаків працювала в суконній, горілчаній, цукровій, полотняній, паперовій, селітроварній і скляній промисловості. На підприємствах, що належали поміщикам, у більшості випадків використовувалася праця кріпаків. На багатьох поміщицьких гуральнях і цукроварнях використовувалася як кріпацька праця, так i вільнонаймана $[15,55]$. Протягом цього періоду число вільнонайманих робітників неухильно зростає, а число кріпаків - скорочується. Загальна кількість робітників напередодні реформи 1861 р., зайнятих на промислових підприємствах і в ремісничих закладах України становила 135 тис. осіб [4,97-98]. Незважаючи на наявність значних груп робітників-кріпаків у цукровій, суконній, полотняній, паперовій і деяких інших галузях, вільнонаймана праця в промисловості України напередодні селянської реформи була переважаючою. Ї̈̈ питома вага дорівнювала 54 \% [15, 56].

Особливістю українського робітничого класу дореформеної доби був його тривалий зв'язок із сільським господарством. У передреформені десятиріччя головним джерелом формування робітничого класу в Україні було селянство. Лише пізніше машинна індустрія цілком відривала робітників від землі. 
У середині XIX ст. в сільському господарстві України панівною залишалася панщинна система господарства. Поміщицьке землеволодіння складало: у Лівобережній і Слобідській Україні - 68-70 \%, у Правобережній - 75 \%, у Південній Україні - $68 \%$. Наприкінці 50 -х років 34,5 тис. державних селян володіли більше ніж 86 тис. дес. землі. Значним землевласником залишалася держава $[12,330]$.

Розшарування селянства на заможних та бідняків підривало основи кріпосницької системи господарства. Заможна верхівка села все більше виходила з-під залежності поміщика, а зубожілі селяни, позбавлені засобів виробництва, неспроможні були виконувати панщину й дедалі більше ставали непридатними для феодально-кріпосницької експлуатації. Напередодні реформи на Правобережній Україні серед поміщицьких селян панщинних кріпаків було 97,4\%, у Лівобережній - 99,3\%, Південній - 99,1\%. Найбільше від поміщицького гноблення страждало селянство Правобережної України, яке експлуатувалося польськими поміщиками.

У 1847-1848 рр. проведено інвентарну реформу поміщицьких селян Правобережжя. За інвентарними правилами, земля, що була в користуванні селян, закріплювалася за ними, регламентувалися повинності селян на користь поміщика. Тяглові селяни повинні були відбувати на тиждень 3 дні 3 упряжкою і 1 жіночий день панщини, інші селяни - 2 дні чоловічих i 1 жіночий. Городники за користування садибою і присадибною ділянкою платили оброк або відробляли 24 дні панщини на рік. Натуральні податки скасовувались. За додаткові повинності селяни мали одержувати платню $[12,334-335]$.

Однак уведення інвентарних правил не заспокоїло селянство. Антикріпосницька боротьба селян у 40-х роках набула масового, наступального характеру. Селяни боролися проти кріпацтва, за визволення 3-під влади поміщиків, за землю і волю, за те, щоб стати вільними виробниками. У 1850-1854 pр. на Лівобережній Україні відбулося 13 селянських виступів, у Новоросії - 7, на Правобережній Україні у 1850-1851 рр. відбулось 47 селянських виступів [3, 132]. У $1856-1860$ рр. в Україні за неповними даними відбулось 276 селянських виступів, в яких брало участь 160 тис. осіб [8, 22]. Криза феодально-кріпосницької системи сягнула своєї вершини, вона перестала відтворювати себе.

Повстання проти поміщиків, царського уряду продемонстрували силу селян, козаків, військових поселенців у боротьбі за соціальні права. Повстанці розхитували основи феодального ладу, наближали його падіння. Також вони будили громадську думку в Україні, сприяли формуванню визвольних революційних ідей, збагатили традиції визвольної боротьби мас проти гнобителів.

Уже за царювання Миколи I створювались «таємні комітети», які мали вирішити селянське питання. Але організований опір поміщиків змусив царя відмовитись від реалізації будь-яких проектів у селянському питанні. Але 
більш далекозорі поміщики побоюючись, щоб селяни не почали розкріпачуватися самі (тобто за допомогою революції), подавали до уряду різні проекти звільнення селян, піклуючись у першу чергу, щоб через скасування кріпацтва поліпшити своє матеріальне становище.

Однак потреба подальшого розвитку продуктивних сил країни змусила царський уряд вдатися до скасування кріпосного права.

Поборниками звільнення селянства від кріпосницького гноблення, захисниками його інтересів були представники політичних організацій та гуртків.

В умовах наростання селянського руху політизується українське національне відродження. Так, у 1846 р. з'явилася таємна політична організація - Кирило-Мефодіївське товариство. Ліквідація кріпосного права, поділу людей на стани, здобуття слов'янської федерації держав стали головними завданнями кирило-мефодіївців. У 1856 р. у Харкові виник таємний політичний гурток, більшість членів якого ставила своїм завданням звільнення селян і заміну монархії республіканським правлінням [8, 105-106].

Підтримували український визвольних рух представники польської інтелігенції. Наприклад, діяльність «Співдружності польського народу» під керівництвом Ш. Конарського. Діяв таємний гурток «Друзі людства», створений на початку Кримської війни. Очолив цей гурток Ю. Котковський. Під час зборів цього гуртка відбувалося читання заборонених творів, також це супроводжувалось обговоренням політичних питань: про становище селянства, Кримську війну та ін. Обговорення селянського питання проходили в дусі програми Ш. Конарського, головним провідником ідей якого в таємному гуртку стала $€$. Волянська. Продовжуючи традиції кириломефодіївців, таємний гурток «Друзі людства» висунув у своїй програмі такі завдання: використати поразку царизму в Кримській війні для його повалення; підготувати селянське повстання.

Виступи селян були підтримані і в передових громадських колах. У боротьбу включалися студенти Київського університету та інших навчальних закладів. У студентських аудиторіях проходили летючі збори, на яких обговорювалося питання про участь студентів у селянських заворушеннях $[14,25-28,31]$.

Таким чином, у процесі капіталістичного розвитку Україна все глибше втягувалась у Російську імперську систему. Проте утвердження товарногрошових відносин впливало на національну самосвідомість значної частини українського етносу. Долався середньовічний ізоляціонізм, відбувалися структурні зміни у складі населення. Нова різночинна інтелігенція та кращі представники національної буржуазії стали носіями українського національного відродження.

Проблема має подальші перспективи дослідження, передусім це стосується соціально-економічного розвитку міст та містечок Наддніпрянщини у першій половині XIX ст. 


\begin{abstract}
Economic development of the Ukrainian provinces in a period before reforms is analyzed. The attention is paid on such fields of industry as a manufactory, machine-building, treatment of metal. Claim of commodity-money relations influenced on national consciousness of considerable part of Ukrainian ethnos.

It is stressed that the tsarist regime primarily defended imperial interests, but could not fail to take into account the need for industrial development of the outskirts, their natural wealth. Protectionism policy contributed to the development of the metallurgical and engineering industries of Ukraine, in particular, the southern regions. This policy intensified after the Crimean War. The state provided assistance to entrepreneurs through government contracts, subsidies, bonuses, preferential tariffs and the like. However, in these conditions, the development of private initiative of the lower classes was limited. The tsarist government made every effort to create ideal conditions for the entrepreneurial activities of the nobility and merchants.

The peculiarity of the Ukrainian working class of the pre-reform period was its long-term relationship with agriculture. In the pre-reform decades, the main source of the formation of the working class in Ukraine was the peasantry. Only later the machine industry completely tore workers from the ground.

In the process of capitalist development, Ukraine was drawn ever deeper into the Russian imperial system. However, the approval of commodity-money relations influenced the national consciousness of a significant part of the Ukrainian ethnos. The medieval isolationism was overcome, structural changes in the population took place. The new heterogeneous intelligentsia and the best representatives of the national bourgeoisie became bearers of the Ukrainian national revival.
\end{abstract}

Key words: Ukraine, Ukrainian provinces, industry, manufactory, peasant, serfdom, cart transport, railways.

\title{
Аннотация
}

Рассматривается экономическое развитие украинских губерний в дореформенный период. Акиентируется внимание на таких отраслях промышленности как мануфактурная, машиностроительная, обработка металла. Утверждение товарно-денежных отношений влияло на начиональное самосознание значительной части украинского этноса.

Подчеркнуто, что чарский режим в первую очередь отстаивал имперские интересы, однако не мог не учитывать потребность промышленного развития окраин, их естественных богатств. Политика протекиионизма содействовала развитию металлургической и машиностроительной отраслей Украины, в частности, южных регионов. Эта политика усилилась после Крымской войны. Государство оказывало предпринимателям помощь путем государственных заказов, субсидий, премий, льготных тарифов и тому подобное. Однако в этих условиях развитие частной инициативы низших сословий было ограничено. Царское 
правительство приложило все усилия для создания идеальных условий для предпринимательской деятельности дворянства и купиов.

Особенностью украинского рабочего класса дореформенного периода была его длительная связь с сельским хозяйством. В передреформенные десятилетия главным источником формирования рабочего класса в Украине было крестьянство. Лишь позже машинная индустрия полностью отрывала рабочих от земли.

В прочессе капиталистического развития Украина все глубже втягивалась в Российскую имперскую систему. Однако утверждение товарноденежных отношений влияло на национальное самосознание значительной части украинского этноса. Преодолевался средневековый изолящионизм, происходили структурные изменения в составе населения. Новая разночинная интеллигенция и лучшие представители национальной буржуазии стали носителями украинского начионального возрождения.

Ключевые слова: Украина, украинские губернии, промышленность, мануфактура, крестьянин, крепостничество, гужевой транспорт, железные дороги.

\section{ДЖЕРЕЛА ТА ЛІТЕРАТУРА}

1. Буравченко Р. В. Історичні умови становлення та розвиток цукрової промисловості в Україні (XIX - початок XX ст.) : автореф. дис. ... канд. іст. наук: 07.00.01. Черкаси, 2006. 20 с.

2. Гончарук Т. Г. Торгівля України першої половини XIX ст.: історія вивчення : автореф. дис. ... док. іст. наук: 07.00.01. Одеса, 1998. 42 с.

3. Гуржій I. О. Боротьба селян і робітників України проти феодальнокріпосницького гніту (з 80 -х років XVIII століття до 1861 року). Київ : Радянська школа, 1958. 168 с.

4. Гуржій I. О. Зародження робітничого класу України (кінець XVIII перша половина XIX ст.). Київ, 1958. 24 с.

5. Дерев'янкін Т. І. Історія народного господарства Української РСР: Економіка досоціалістичних формацій. Київ : Наук. думка, 1983. 467 с.

6. Дмитриев Н. И., Колпычев В. В. Судостроительные заводы и судостроение в России и за границей. СПб., 1909. 867 с.

7. Залесский Н. А. «Одесса» выходит в море. Возникновение парового мореплавания на Черном море (1827-1855 гг.). Ленинград, 1987. 246 с.

8. Іванова Л. Г., Іванченко Р. П. Суспільно-політичний рух $60-x$ років XIX століття в Україні: до проблеми становлення ідеології. Київ : Міжнар. ін-т лінгвістики і права, 2000. 349 с.

9. Курінна Т. М. Розвиток благодійності на середньому Подніпров'ї (кінець XVIII - початок XX ст.) : автореф. дис. ... канд. іст. наук: 07.00.01. Черкаси, 2004. $18 \mathrm{c}$.

10. Лазанская Т. И. Государственные крестьяне Украины в период кризиса феодально-крепостнической системы. Київ, 1989. 125 с. 
11. Лазанська Т. Історія підприємництва в Україні (на матеріалах торговопромислової статистики ХІХ ст.). Київ : Ін-т історії України НАН України, 1999. 282 с.

12. Лановик Б. Д., Матисякевич 3. М. Економічна історія України і світу. Київ : Вікар, 2004. 486 с.

13. Лановик Б. Д., Матисякевич 3. М. Україна і світ. Історія господарства від первісної доби і перших цивілізацій до становлення індустріального суспільства. Київ : Генеза, 1994. 368 с.

14. Марахов Г. И. Социально-политическая борьба на Украине в 20-40-е годы XIX века. Київ : Вища школа, 1979. 145 с.

15. Мельник Л. Г. Промисловий переворот в Росії і на Україні. Київ, 1969. $68 \mathrm{c}$.

16. Рижева Н. О. Морське суднобудування в Україні (XIX - поч. XX ст.). Науковий вісник Ізмаїльського державного гуманітарного університету. 2004. Вип. 17. С. 29-32.

17. Русское судоходство. Торговое и промысловое на реках, озерах и морях. Ежемесячный журнал. 1896. № 175. С. 122-134.

18. Слабеев И. С. Торгово-транспортный (чумацкий) промысел и его роль в социально-экономическом развитии Украины в XVIII - первой половине XIX в. : автореф. дис. ... канд. ист. наук: 07.00.01. Київ, 1960. 18 с.

19. Суровцева I. Ю. Меценатство в Україні другої половини XIX - початку XX ст. : автореф. дис. ... канд. іст. наук: 07.00.01. Донецьк, 2006. 19 с.

\section{References}

1. Buravchenko, R. V. (2006). Istorychni umovy stanovlennya ta rozvytok tsukrovoyi promyslovosti v Ukrayini (XIX - pochatok XX st.) [Historical conditions of the establishment and development of the sugar industry in Ukraine (XIX early XX centuries)] : avtoref. dys. ... kand. ist. nauk: 07.00.01. Cherkasy.

2. Honcharuk, T. H. (1998). Torhivlya Ukrayiny pershoyi polovyny XIX st.: istoriya vyvchennya [Trade of Ukraine in the first half of the nineteenth century: the history of studying] : avtoref. dys. ... dok. ist. nauk: 07.00.01. Odesa.

3. Hurzhiy, I. O. (1958). Borot'ba selyan i robitnykiv Ukrayiny proty feodal'nokriposnyts'koho hnitu (z 80-kh rokiv XVIII stolittya do 1861 roku) [The struggle of the peasants and workers of Ukraine against feudal feudal oppression (from the 80 years of the XVIII century to 1861)]. K. : Radyans'ka shkola.

4. Hurzhiy, I. O. (1958). Zarodzhennya robitnychoho klasu Ukrayiny (kinets' XVIII - persha polovyna XIX st.) [The birth of the working class of Ukraine (the end of the XVIII - the first half of the XIX century)]. Kyiv.

5. Derev'yankin, T. I. (1983). Istoriya narodnoho hospodarstva Ukrayins'koyi RSR: Ekonomika dosotsialistychnykh formatsiy [The history of the national economy of the Ukrainian SSR: The economy of the pre-socialist formations]. Kyiv : Nauk. dumka. 
6. Dmitriev, N. I., Kolpychev, V. V. (1909) Sudostroitel'nye zavody i sudostroenie $\mathrm{v}$ Rossii i za granicej [Shipbuilding plants and shipbuilding in Russia and abroad]. SPeterburg.

7. Zalesskij, N. A. (1987). «Odessa» vyhodit v more. Vozniknovenie parovogo moreplavanija na Chernom more (1827-1855 gg.) [ «Odessa» goes to sea. The emergence of steam navigation on the Black Sea (1827-1855)]. Lviv.

8. Ivanova, L. H., Ivanchenko R. P. (2000). Suspil'no-politychnyy rukh 60-kh rokiv XIX stolittya v Ukrayini: do problemy stanovlennya ideolohiyi [Socialpolitical movement of the 60s of the XIX century in Ukraine: to the problem of the formation of ideology]. Kyiv : Mizhnar. in-t linhvistyky i prava.

9. Kurinna, T. M. (2004). Rozvytok blahodiynosti na seredn'omu Podniprov'yi (kinets' XVIII - pochatok XX st.) [Development of charity on the average Dnieper (the end of the XVIII - the beginning of the XX century)] : avtoref. dys. ... kand. ist. nauk: 07.00.01. Cherkasy.

10. Lazanskaya, T. I. (1989). Gosudarstvennye krest'yane Ukrainy v period krizisa feodal'no-krepostnicheskoi sistemy [State peasants of Ukraine during the crisis of the feudal-serf system]. Kyiv.

11. Lazans'ka, T. (1999). Istoriya pidpryyemnytstva $v$ Ukrayini (na materialakh torhovo-promyslovoyi statystyky XIX st.) [The history of entrepreneurship in Ukraine (based on the materials of trade and industrial statistics of the XIX century)]. Kyiv : In-t istoriyi Ukrayiny NAN Ukrayiny.

12. Lanovyk, B. D., Matysyakevych Z. M. (2004). Ekonomichna istoriya Ukrayiny i svitu [Economic History of Ukraine and the World]. Kyiv : Vikar.

13. Lanovyk, B. D., Matysyakevych Z. M. (1994). Ukrayina i svit. Istoriya hospodarstva vid pervisnoyi doby i pershykh tsyvilizatsiy do stanovlennya industrial'noho suspil'stva [Ukraine and the world. History of the economy from the primitive age and the first civilizations to the formation of an industrial society]. Kyiv : Geneza.

14. Marakhov, G. I. (1979). Sotsial'no-politicheskaya bor'ba na Ukraine v 20-40-e gody XIX veka [Socio-political struggle in Ukraine in the 20-40's of the XIX century]. Kyiv : Vishcha shkola.

15. Mel'nyk, L. H. (1969). Promyslovyy perevorot v Rosiyi i na Ukrayini [Industrial revolution in Russia and Ukraine]. Kyiv.

16. Ryzheva, N. O. (2004). Mors'ke sudnobuduvannya v Ukrayini (XIX - poch. XX st.) [Marine Shipbuilding in Ukraine (XIX - early XX centuries)] // Naukovyy visnyk Izmayil's'koho derzhavnoho humanitarnoho universytetu. Vyp. 17. S. 29-32.

17. Russkoe sudokhodstvo. Torgovoe i promyslovoe na rekakh, ozerakh i moryakh [Russian shipping. Trade and fishery on rivers, lakes and seas]. Ezhemesyachnyi zhurnal. 1896. № 175. S. 122-134.

18. Slabeev, I. S. (1960). Torgovo-transportnyi (chumatskii) promysel i ego rol' v sotsial'no-ekonomicheskom razvitii Ukrainy v XVIII - pervoi polovine XIX v. [Trade-transport (tchoomak) fishery and its role in the socio-economic 
development of Ukraine in the XVIII - first half of the XIX century] : avtoref. dis. ... kand. ist. nauk: 07.00.01. Kyiv.

19. Surovtseva, I. Yu. (2006). Metsenatstvo v Ukraïni drugoï polovini XIX pochatku XX st. [Patronage in Ukraine in the second half of the XIX and early $X X$ centuries] : avtoref. dis. ... kand. ist. nauk: 07.00.01. Donets'k.

УДК 94(498.7): 528 «1818/1891»

\section{ДІЯЛЬНІСТЬ БЕССАРАБСЬКОЇ ОБЛАСНОЇ МЕЖОВОЇ КОНТОРИ (1818-1891 РР.): ЗАКОНОДАВЧІ НОВАЦІЇ ТА ПОВСЯКДЕННА ПРАКТИКА}

\section{Петрова Інна, Петров Олексій}

Статтю присвячено проблемам становлення системи обліку земельних ресурсів, реформування поземельних відносин у Бессарабській області відповідно до загальноросійських стандартів. У студіях аналізуються нормативно-правові документи, на підставі яких проводилося Генеральне межування бессарабських земель $і$ вирішувались усі юридичні казуси, що виникали під час експедииій. Серед таких документів слід назвати «О обмежевании казенных земель Бессарабской области и разделении оных на участки (№ 26719 от 7 марта 1817 г.)», «О учереждении особой Комиссии для составления правил генерального размежевания земель Бессарабской области (№ 23578 от 17 октября 1849 г.)», «Об изменении порядка размежевания земель Бессарабской губернии: Высочайше утвержденное мнение Государственного Совета (№ 1591 от 19 мая 1883 г.)» тощо. Досліджено два підходи, запропоновані російським урядом для проведення межувальних робіт у регіоні: один - для казенних земель, інший - для приватновласницьких. Так, для межування казенних земель була спрямована експедиція, яку складали вісім землемірів із прилеглих до Бессарабської області губерній. Для межування приватновласницьких, иерковних, монастирських та міських земель в Оргіївському, Хотинському та Ясському повітах, а також розгляду поземельних конфліктів в Аккерманському, Ізмаїльському та Бендерському повітах 29 квітня 1818 . було створено Бессарабську обласну межову контору. Крім того, у статті досліджуються технічні засади межування й основні проблеми, що уповільнювали темпи обстеження земельних ділянок. На думку автора, це панування традиційних форм землеволодіння та землекористування в регіоні, саботування місиевими жителями заходів Генерального межування, етнічна строкатість Бессарабської області, значна кількість земельних конфліктів, відсутність належної комунікації між населенням та владними інституціями. 